\title{
腰部脊柱管狭窄症手術例の検討
}

$\begin{array}{lllll}\text { 琉球大学整形外科 } & & & & \\ \text { 金 城 幸 } & \text { 雄・佐 } & \text { 藤 } & \text { 栄 } \\ \text { 西 平 竹 } & \text { 志・屋 } & \text { 良 哲 也 } \\ \text { 棚 原 } & & \text { 豊・森 } & & \text { 諭 史 } \\ \text { 茨 木 邦 夫 } & & & \\ \text { 琉球大学保健管理センター } & & & \\ \text { 高 良 宏 明 } & & \end{array}$

\section{Clinical and Radiological Evaluation of Posterior Decompression for Lumbar Canal Stenosis}

by

\author{
Yukio Kinjo, Sakae Sato, Takeshi Nishihira, Tetsuya Yara, \\ Yutaka Tanahara, Satoshi Mori and Kunio Ibaraki \\ Department of Orthopaedic Surgery, \\ School of Medicine, University of the Ryukyus
}

\section{Hiroaki Takara}

Health Administration Center, University of the Ryukyus

\begin{abstract}
Clinical results of 38 cases of lumbar canal stenosis treated by posterior decompression were studied and 10 cases were further evaluated radiologically.

In most cases intermittent claudication, intermittent sense of retention, pollakisuria and perineal dysesthesia disappeared postoperatively. However, motor weakness and subjective sensory disturbances, especially in the S1 innervating area persisted postoperatively in the majority of cases.

Ten cases were evaluated by both pre- and postoperative CTM, and stenotic changes in the lateral recess were found preoperatively in 4 cases. Three of these cases recovered from intermittent claudication after surgery, although their post-operative CTM revealed that no decompression had been done on the lateral recess. These results suggest that in some cases intermittent claudication is not caused by stenotic changes of the lateral recess.
\end{abstract}

Key words : lumbar canal stenosis（腰部脊柱管狭窄症）, posterior decompression（後方除圧）, lateral recess (外側陥凹), residual symptoms (遺残症状)

は じめに

腰部脊柱管狭窄症において，除圧術後に間歇性跛行 などの歩行時症状は改善するが，安静時症状の遺残す る例が見られる。そこで, 遺残症状の分析と除圧範囲 を中心に検討を行った。
間歇性跛行を主訴とし，後方除圧を施行された腰部 脊柱管狭窄症の 38 例で, 変形性腰椎症によるもの 25 例, 変性过りによるもの 13 例であった. 性別は男性 25 例, 女性 13 例で年令は 48 歳〜81 歳, 平均 64 歳 3 力月 であった。術式は椎弓切除術が 28 例で, 除圧範囲は 1 
$\sim 4$ 椎間, 平均 2.2 椎間であり, 内側椎間関節切除術 が 10 例で, 除圧範囲は $1 \sim 3$ 椎間, 平均 1.9 椎間であ った。除圧術は原則として画像上の圧迫部位全てに行 つた。術後観察期間は 1 年〜 7 年, 平均 2 年 11 力月で あった。

\section{方法}

歩行時症状では間歇性跛行と間歇性会陰部症状の転 帰および遺残率を検討した。安静時症状としては筋力 低下, 他覚的知覚障害, 自覚的知覚障害および尿失禁 などの項目別に転帰と遺残率を調べ, さらに神経根領 域別にも検討を行った。

術後 CTM を撮り得た 10 例においては脊柱管狭窄 の型分類と除圧された範囲について調べた．評価の方 法としては, まず椎弓根レベルで春柱管をトレースし, これを椎間板直下レベルの外側楩凹部に重ね合わせて 同部を評価した。まず術前 CTM において外側陷凹部 が椎弓根内縁より内側にせりだしているものを外側陥 凹型 (以下，外側型)，内側にせりだしていないものを 中心型，外側型と中心型の合併を外側+中心型と分類 した (図 1 )。次に術後 CTM から外側陥凹部と中心部 の除圧の良否を判定した。

\section{結果}

1. 歩行時症状

1）間歇性跛行

間歇性跛行は術前 38 例全例にみられ, 術後は消失が 33 例, $87 \%$ で，遺残は 5 例，13\%であった。しかし遺

\section{外側型 中心型}

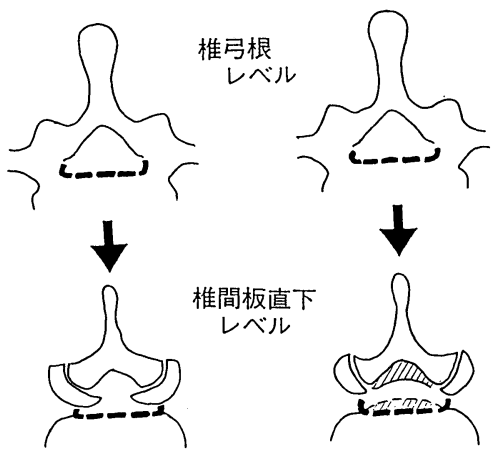

図 1.CTM による狭窄の型と除圧範囲の評価法
残した 5 例についてみると, 3 例で歩行距離が延長し, 2 例で歩行距離は延長しなかったが, 疼痛がシビレへ と変化し，患者は 5 例とも改善ととらえていた。

間歇性跛行消失例の罹病期間は 2 力月 20 年, 平均 4 年 7 力月, 遺残例は 2 年 15 年, 平均 5 年 7 力月で あり，両群に有意差はなかった。

2 ）間歇性陰部症状

術前 7 例にみられたが全例消失していた。

2. 安静時症状

33 例， $87 \%$ に術前なんらかの安静時症状がみられ， 術後回復が 13 例, $39 \%$, 遺残 20 例, $61 \%$, 歩行時 症状に比べて成績が悪かった。

安静時症状消失例の罹病期間は 3 力月～20 年, 平均 4 年 3 力月で, 遺残症例は 2 力月 15 年, 平均 5 年 6 カ月であり，両群に有意差はなかった。

1) 項目別

MMT4 以下の筋力低下が術前 16 例にみられ術後 は完全回復が 4 例, $25 \%$, 完全には回復しなかった例 が 12 例， 75 \%であった。他覚的知覚障害は 30 例にみ られ，回復が 20 例，67\%で，遺残が 10 例，33\%であ った. シビレなどの自覚的知覚障害は術前 18 例で, 回 復が 6 例 $33 \%$ ，遺残が 12 例，67\%であった。また尿 失禁の 1 例は回復しなかった。

以上から項目別では，筋力低下と自覚的知覚障害お よび尿失禁の遺残率が高かった。

2 ) 神経根領域別

L 5 神経根領域では筋力低下が術前 16 例で, 回復が 7 例, $44 \%$, 遺残が 9 例, $56 \%$ と比較的高い遺残率で あった. 他覚的知覚障害は術前 27 例にあり, 回復が 20 例, $74 \%$, 遺残が 7 例 $26 \%$ であった. 自覚的知覚障害 は 11 例で回復が 7 例， $63 \%$ ，遺残が 4 例，37\%であ つた。

S 1 神経根領域では筋力低下が術前 8 例で, 回復が 1 例, $13 \%$, 遺残が 7 例, $87 \%$ と高率に遺残していた。 他覚的知覚障害は 28 例で, 回復が 19 例, $68 \%$, 遺残 が 9 例, $32 \%$ であった. 自覚的知覚障害は 17 例で, 回 復が 4 例， $24 \%$ ，遺残が 13 例， $76 \%$ と高い遺残率で あった。

このようにL 5 領域では筋力低下，S 1 領域では筋 力低下と自覚的知覚障害が高率に遺残していた。

3 . 狭窄の型分類と除圧範囲

検討した 10 例は多椎間に除圧術が施行されたが, 術 中所見では L $4 / 5$ 以外には著明な圧迫はみられず，全 
例 L4/5レベルが責任高位と考えられた。 CTM では L4/5レベルにおける狭窄の型は外側型 1 例, 中心型 6 例，外側＋中心型 3 例であった。 それぞれの狭窄部に ついて除圧の良否をみると, 外側型と中心型では除圧 範囲良好であったが，外側十中心型の 3 例では外側陥 凹部の除圧が不良であり, 中心部のみ除圧されていた。 しかし, 術後は全例, 間歇性跛行が消失していた。

症例

66 歳, 男性. 変形性腰部脊柱管狭窄症. 主訴は 200 $\mathrm{m}$ の間歇性跛行で, 安静時症状として左 L 5 と左 S 1 の神経根領域に MMT4 の筋力低下が, 両側 L 5, S 1 の神経根領域に他覚的知覚障害がみられた。術前の画 像は脊髄腔造影において L4/5 の完全ブロック，L3/4 および L5/S1 の狭窄を呈し(図 2-a，b)，CTMで L4/5レベルの狭窄の型は外側十中心型であった（図

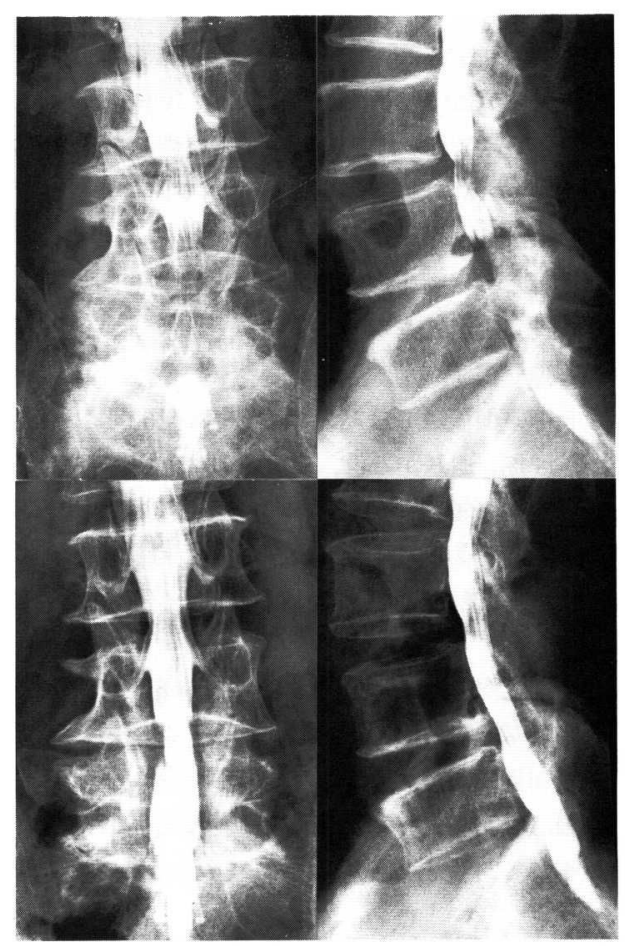

図 2, 脊髄腔造影

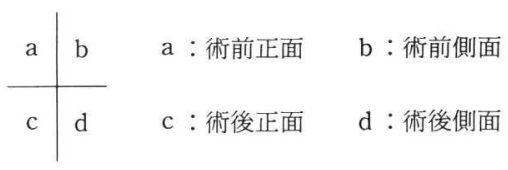

$3-\mathrm{a}, \mathrm{c})$.

L 3 から L 5 の椎弓切除を行った. 術中は L4/5レ ベルで肥厚した黄色鞄帯と下関節突起による圧迫が著 明であった。中心部のみの除圧で神経根が確認できた ので, 外側陷凹部の除圧は行わなかった. なお L3/4, L5/S1 レベルでの圧迫はほとんどなかった。

術後脊髄腔造影で硬膜管の膨らみが見られたが, L 5 神経根は描出されないままだった。(図 $2-\mathrm{c}, \mathrm{d}$ ). 術後 CTM では L4/5 レベルの外側陥山は除圧されて いなかった（図 $3-b, d)$.

間歇性跛行は消失し, 術前の安静時症状であった両 側 L 5 神経根領域の他覚的知覚障害と左 L 5 神経領域 の筋力低下, および右 S 1 神経根領域の他覚的知覚障 害も回復した. しかし左S 1 神経根領域の他覚的知覚 障害と筋力低下は遺残した。

\section{考察}

\section{1 、遺残症状に関する諸家の報告との比較}

歩行時症状についてみると間歇性跛行, 間歇性会陰

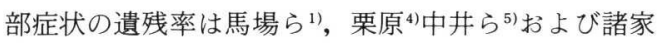
の報告37779111) と同様に良好であった。

安静時症状についてみると筋力低下と自覚的知覚障

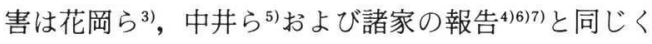

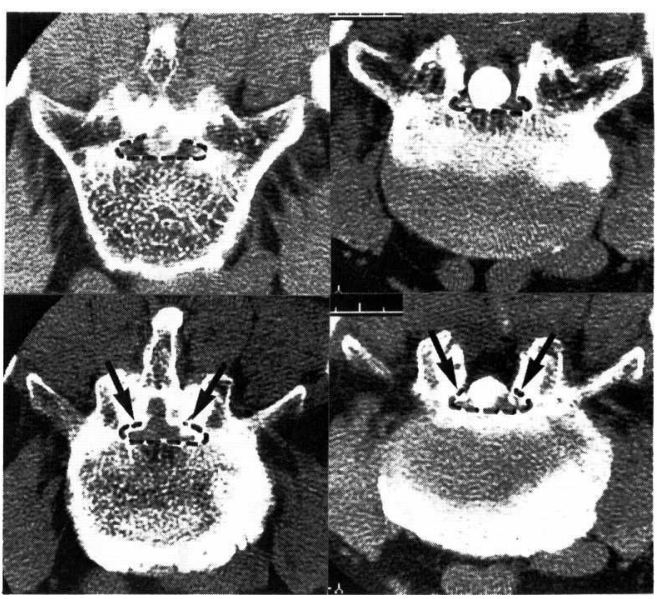

図3.CTM（L4/5レベル）

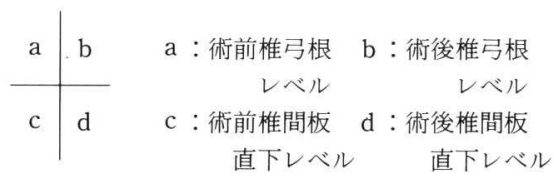


回復が悪かった。しかし，他覚的知覚障害の遺残率は

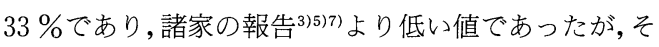
の理由は不明であった。

2. 安静時症状の神経根別遺残率について

我々の渉猟しえた限り，神経根別に遺残症状を検討 した報告はなかった。今回の結果では L 5 および S 1 神経根領域の筋力低下と S 1 神経根領域のシビレの遺 残が高率であった。

S 1 神経根領域のシビレが高率に遺残した理由とし ては頸髄症の術後に指先のシビレ遺残を訴える例が多 いことと同様に，足底の接地によりシビレを意識する 機会が多いこともその理由の一つと考えられた。

呈示症例のように術後の画像所見でL 5 神経根の描 出が不良のままで, S 1 神経根の描出が良好にもかか わらずL 5 神経根領域のみ回復し，S 1 神経根領域の 回復しなかった症例がもう 1 例あった。この症状は中 心型であったが，この 2 症例から S 1 神経根の非可逆 性が L 5 神経根のそれよりも強い可能性が示唆され た。

3 . 間歇性跛行に対する外側陥凹の関与

Verbiest は外側陥凹切除の必要性を報告し ${ }^{5)}$, その 後, Epstein, Schatzker らもその重要性を説き1)4, 一 般に支持されるようになっている.

しかし，今回の症例の中には外側陥凹が除圧不足だ ったにもかかわらず間歇性跛行が消失した外側十中心 型の 3 例が含まれていた。呈示例を含めた 2 例では, 外側陷凹を除圧せずとも中心部の除圧だけで神経根が 弛緩した状態になった。つまり中井らが狭窄椎間では 馬尾に加えて神経根も内側に偏位しており, 神経根が 外側陷凹をはずれて走行しているので外側陷凹除圧は 不要 ${ }^{2)}$ をる病態であったと思われた。

残りの 1 例では神経周囲の癒着が高度だったので, 結果的に硬膜管のみ確認したが神経根は確認できなか った。この例で間歇性跛行が消失した理由としては， 中井らの説の他に中心型狭窄が symptomaticで, 外 側型狭窄がまだ asymptomatic の stage であったこ とも考えられた。

我々は神経根自体の非可逆性, 中井らの内側偏位説, および外側陷凹部に存在する神経根が symptomatic がどうかを確実に証明することができない現在，外側 陥凹の除圧は必要と考えている。

\section{ま と め}

1. 腰部脊柱管狭窄症に対する除圧術後, 歩行時症 状の改善は良好であったが, 安静時症状の遺残が高率 にみられた。

2. 安静時症状の遺残は L 5 およびS 1 神経根領域 の筋力低下と S 1 領域の自覚的なシビレに高率であっ た.

3. 特に S 1 神経根領域の遺残率が高かった理由と して，足底の接地によりシビレを意識する機会が多い ことや神経根の非可逆性が考えられた。

4. 間歇性跛行に対しても，外側陥凹狭小化が関与 していない例も，確かになると思われた。

\section{文献}

1）馬場久敏活か：馬尾性間歇性陰茎勃起症状の臨床的 検討. 整形・災害外科, 31：507-515，1988.

2) Epstein, J. A., et al.: Nerve root compression associated with narrowing of the lumbar spinal canal. J. of Neurol. Neurosurg. Psychiat., 25 : 165176, 1962.

3）花岡 徹ほか：最近 5 年間における腰部脊柱管狭窄 症の手術成績と成績不良例の検討. 臨床整形外科, 27 : 443-449， 1992.

4）栗原 章：腰部脊柱管狭窄症に対する広範椎弓切除 術の術式と治療成績. 整形外科 Mook, No41 : 220-230, 1985.

5）中井 修，山浦伊裟吉：腰部脊柱管狭窄症に対する 拡大開空術. 整形外科 Mook, No41 : 231-242, 1985.

6）小田裕涓以か：腰部脊柱管狭窄症に対する腰椎椎間 拡大術の術後長期成績. 臨床整形外科, $27: 403-410$, 1992.

7）岡野克紀ほか：腰部脊柱管狭窄症に対する部分的椎 間関節切除術. 臨床整形外科, 19：749-754，1984.

8) Schatzker, et al.: Spinal stenosis, a cause of cauda equina compression. J. B. J. S., 50-B(3) : 606-618, 1968.

9）関口哲也ほか：腰部脊柱管狭窄症の手術成績．整形 外科, $41: 633-618,1984$.

10) Verbiest, H.: A radicular syndrome from developmental narrowing of the lumbar vertebral canal. J. B. J. S., 36-B(2) : 230-237, 1954.

11）渡邊 洋ほか：腰部脊柱管狭窄症に対する手術療法 の検討.日整会誌，63：728-740，1989.

12）吉田雅嗣ほか：腰部脊柱管狭窄症における間歇性陰 茎勃起. 整形外科, $42 ： 217-220,1991$. 